\title{
Management Analysis System Inventory of FTTX (Fiber To The X) With GE- Smallworld Using ITIL Method Domain Service Operation PT Telkom Akses Regional 1 Sumatera
}

\author{
Putra Edi Mujahid $^{\# 1}$, Nilo Legowo ${ }^{* 2}$ \\ " Information System Management Department, \\ BINUS Graduate Program Master of Information System Management, \\ Bina Nusantara University, Jakarta 11480, Indonesia \\ ${ }^{1}$ putra.mujahid@binus.ac.id, ${ }^{2}$ nlegowo@binus.edu
}

\begin{abstract}
In an era of increasingly competitive business where the speed of service and decision making has become a necessity to win the competition. Where is PT. Telkom Akes is one of the companies engaged in telecommunication network infrastructure that is very influential on technology facilities and information systems to run the company's business strategy. A must for a company to continue to improve the quality of the technology and information systems. In improving the quality of information technology services can use one of the best practices of the IT governance framework, namely Information Technology Infrastructure Library (ITIL) with one of its domains is service operation, because service operation is a stage of lifecycle that covers all daily operational activities of managing services IT. thus IT organizations are expected to be able to know the maturity level of IT systems within the company that can be used as a basis and direction in improving their services. From the results of the study, it was found that the level of maturity intended was basically the level of maturity of the average company at level 3. To maintain the quality of IT services in the company it was suggested that the evaluation of IT governance be carried out continuously over a period of time, in order to obtain the desired level of maturity can be achieved.
\end{abstract}

Keyword - Service Management, ITIL, service operation, Level of Maturity

\section{INTRODUCTION}

One of the investment strategies in the field of corporate information technology applied in the SDI Division (Survey Design Inventory) of PT Telkom Akes is to implement an integrated and accurate data and design inventory system using GE-Smallworld tools. With the help of GE-Smallworld tools, it allows us to design a telecommunications network infrastructure in this case is a broadband network with fiber optic technology to all areas needed with the help of maps, namely google earth and other supporting folder applications.

SDI Division (Survey Design Inventory) is a division that specifically handles the design and data of fiber optic networks from planning to production equipment built is completed. Before raising the topic of this research, the author had conducted a survey in advance on GE-Smallworld work processes including constraints experienced by employees in the position of drafter, and the results of the survey there were obstacles experienced by employees of the drafter in carrying out their activities at GE-Smallworld. the drafter in achieving the drafter's own productivity and performance because a lot of time wasted caused obstacles experienced during his activities using GE-Smallworld, therefore the author wanted to examine and analyze the obstacles that disrupt the work process carried out by drafter with GE tools -Smallworld, so that the obstacles and problems that occur when the drafter uses GE-Smallworld can be immediately identified and can be a reference for making decisions / actions to solve them.

To find out, and analyze the constraints experienced by the GE-Smallworld drafter, the author conducted a study using the ITIL V3 framework entitled "AManagement Analysis System Inventory of FTTx (Fiber To The X) Using GE-Smallworld ITIL Method Domain Service Operation PT Telkom Akses Regional 1 Sumatera".

The following is the obstacle data reported by the drafter when carrying out GE-Smallworld activities reported by the drafter in the period November 2018, December 2018 and January 2019. 


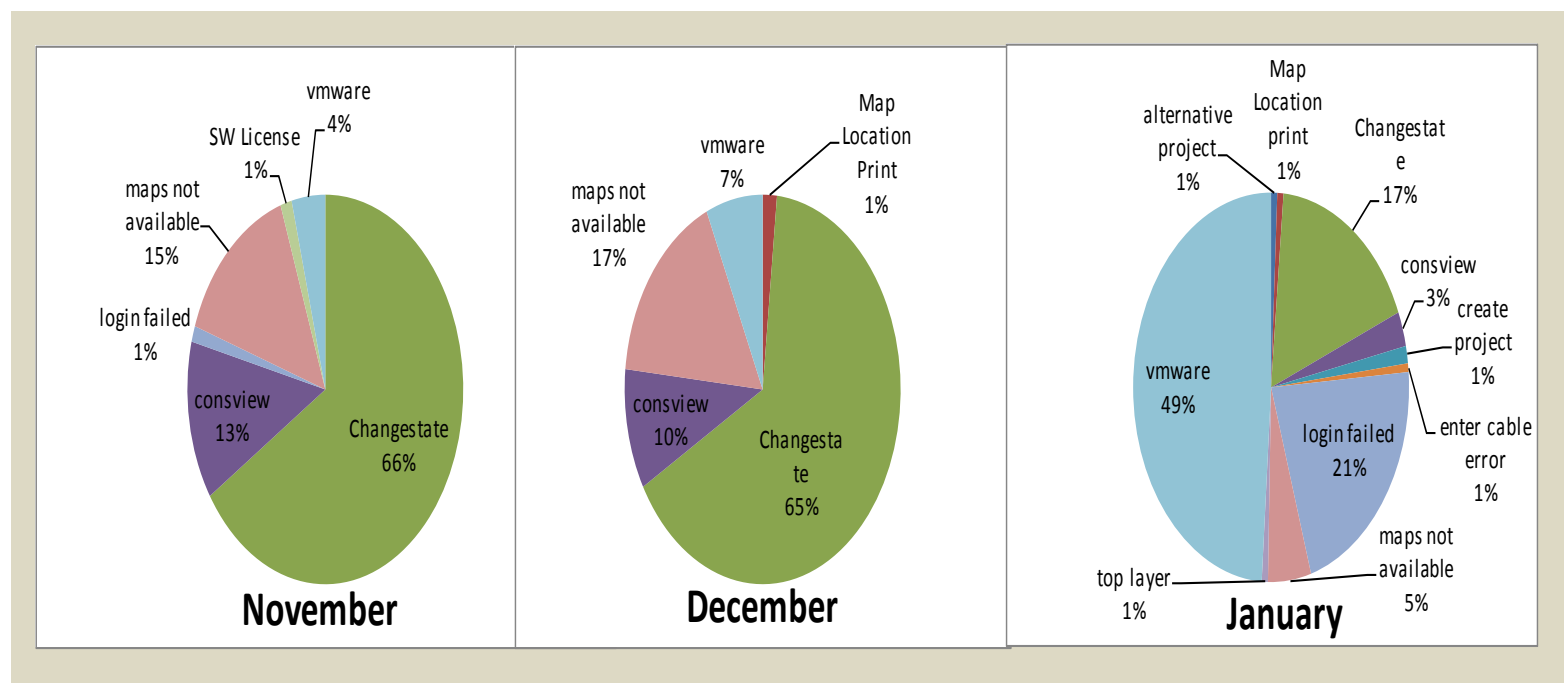

Fig. 1. GE-Smallworld constraints in a period of 3 months of drafter report

FTTx optical fiber network (fiber to the $\mathrm{x}$ ) has at least 2 active devices installed in the central office and the other is installed near or at the customer's location. Based on the location of the placement of active devices installed near or at the customer's location, there are several configurations, namely fiber to the building, fiber to the zone, fiber to the curb, and fiber to the home.[1] .

ITIL offers a set of best practices for managing information technology services and is one of the most used and accepted approaches by management in the world for information technology services (Xiaojun Tang and Yuki Todo, 2013) [2]. The ITIL V3 Framework is a method that can be used in the application of information technology governance that has standardized information technology services and has best practices, so that ITIL V3 can be used as a guide for conducting evaluation and improvement processes in order to improve the maturity and quality of information technology systems in GE-Smallworld.

\section{LITERATURE REVIEW}

\section{A. ITIL}

ITIL defines information technology as technology utilization for storage, communication or processing information. This technology generally includes computers, telecommunications, applications and software. While information can includes business data, sound, images, videos and so. Information technology often used to support the business process through IT services. [15].

ITIL V3 was published in 2007 and consists of five core books (core) which discuss service lifecycle, with Official Introduction as the sixth book. [3] Framework ITIL's work aims to be sustainable improve IT operational efficiency and quality of customer service. [14]

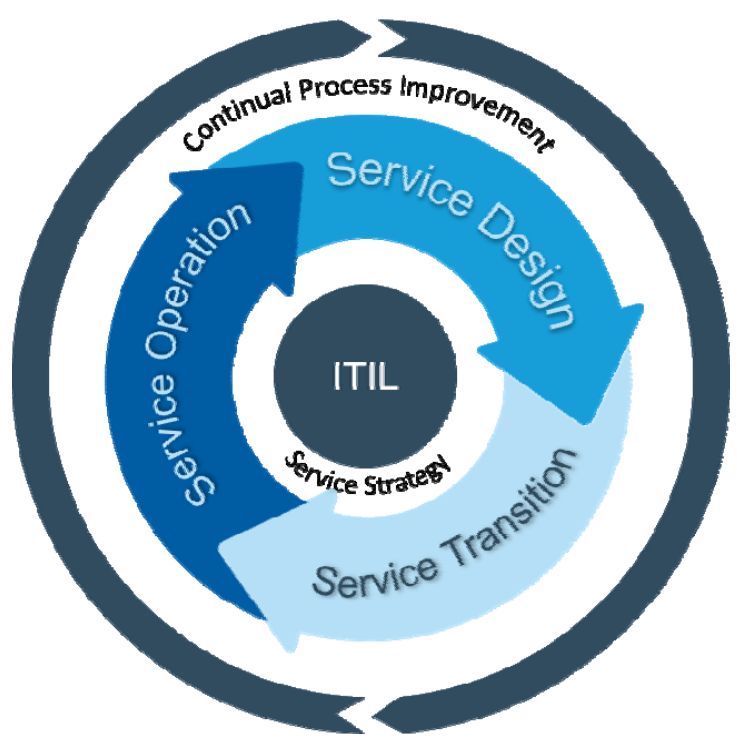

Fig. 2. IT Service Lifecycle [4] 
ITIL service cycle in figure 2 :

1. Service Strategy is a guide for determining what strategies will be used to implement the system.

2. Service Design is to provide guidance for designing information technology services so that they can be implemented.

3. Service Transition is a guide to knowing what needs will be needed to realize them in the next step.

4. Service Operation is a daily operational activity for managing information technology services.

Service Operation, The purpose of Operation Services is to provide an agreed level of service to users and customers, and to manage applications, technology and infrastructure that support giving service.

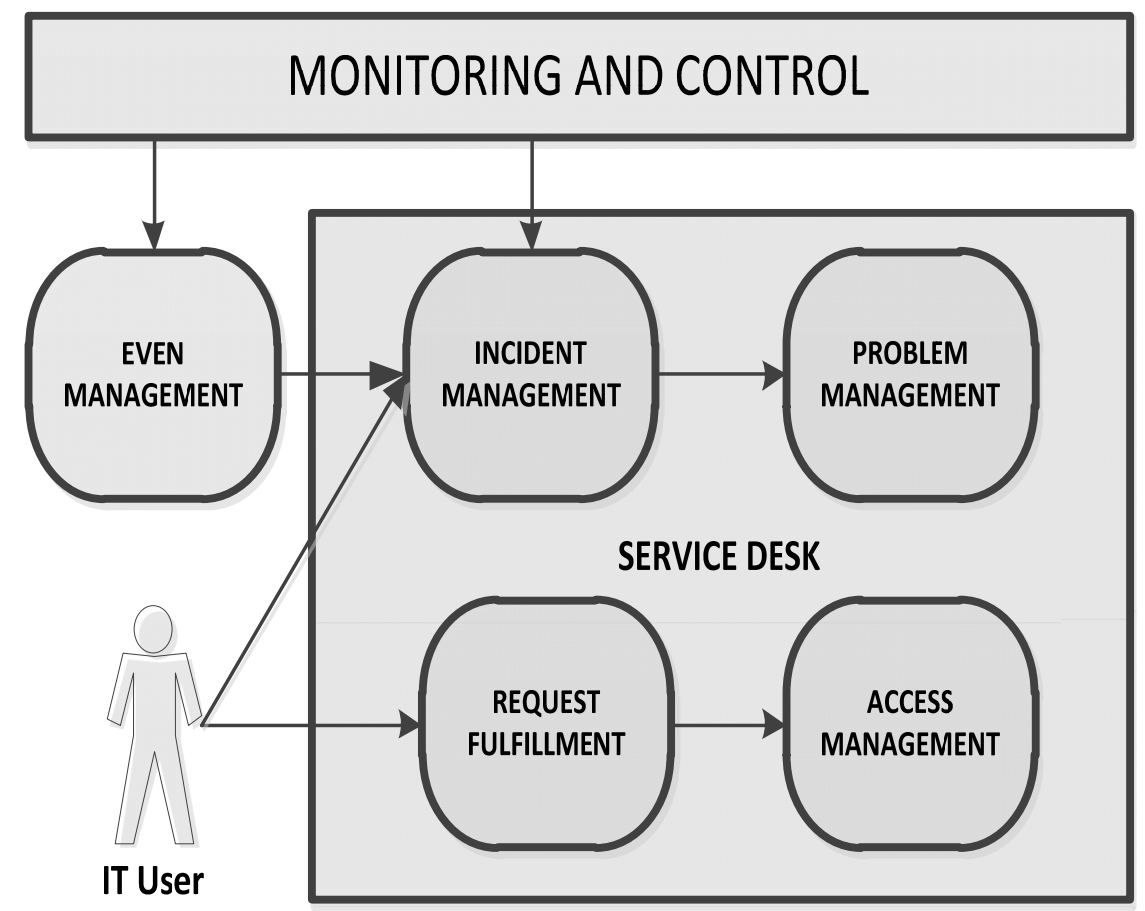

Fig. 3. The process and activities of Service Operation [12]

The processes in the Service Operation : [13]

1. The purpose of Event Management is to detect events and decide what approaches need to be taken for the event. There is a difference between monitoring and Event Management, Event Management focuses on the results and detection. While monitoring is needed to detect.

2. Incident Management is the process of handling all incidents, including failure, with technical staff or automatically detected and reported by toolmonitoring events. The aim is to restore normal service activities as quickly as possible and minimize the influence on business activities while ensuring that the best stages of service quality and availability are arranged. The difference between Incident Management and Problem Management is the way it is resolved. Incident Management will solve the problem if a problem occurs. While the Management Problem will resolve before the problem happened, and it was done permanently.

3. Request Fulfillment is a step where a user can do request to be able to develop services. The aim is for the people users can request and receive services according to standards and to enable IT to fulfill services.

4. Access Management is a process authorizing the user to do so use service. Based on ability to identify users who has the right accurately and then set the ability to access services. The purpose is provide the right for the user to be able to use service.

5. Problem Management is analysis done to find out the cause main and resolve the causes of permanent incidents, problem activities Management is carried out proactively. The purpose of the Problem Management is to minimize the negative consequences of an incident caused by existence damage to IT infrastructure, and also to avoid incidents. 


\section{B. ITSM (Information Technology Service Management)}

IT Service Management or also called Information Technology Service Management (ITSM) is planned and controlled utilization of IT assets, people and processes to support business operational needs as efficiently as possible and ensure that the organization has ability quickly and effectively to respond to events / situations that are not desirable and continuously evaluating process and performance in order identify and implement opportunities for improvement .[16]

Service is something valuable that is given to customers. IT Service Management, also known as Information Technology Service Management (ITSM), is a planned and controlled utilization of IT assets, people and processes to support business operational needs as efficiently as possible and ensure that organizations have the ability to respond quickly and effectively to events / situations that unwanted and continuously evaluating processes and performance in order to identify and implement opportunities for improvement . According to Office Government Commerce, or better known as OGC (2007, p28), "A service is a means of delivering value to customers by facilitating outcomers to achieve without the ownership of specific costs and risks." IT is one of the service categories that used by businesses IT as a service is usually in the form of applications and infrastructure bundled and offered as services by the internal IT of the organization or external service providers.[4],[11].

IT organizations that fail to follow these changes will soon be far behind. Therefore, IT service providers must shift their focus from technology and internal organizations to the quality of services they provide for user satisfaction. If IT service providers cannot provide proactive services and added value to users, we can say the level of IT services is low, even though IT service providers have a large infrastructure with the latest technology. IT departments must try to achieve a proactive level of IT service management processes so that they can succeed deploy ITSM technology.

TABLE I. Process maturity scale [5]

\begin{tabular}{|c|c|c|c|c|c|}
\hline $\mathbf{0}$ & 1 & 2 & 3 & 4 & 5 \\
\hline None & Initial & Repeatable & Defined & Managed & Optimized \\
\hline $\begin{array}{l}\text { Process not } \\
\text { performed } \\
\text { at all and no } \\
\text { one is } \\
\text { aware of } \\
\text { what is } \\
\text { needed }\end{array}$ & $\begin{array}{l}\text { There is } \\
\text { awareness, } \\
\text { but } \\
\text { processes are } \\
\text { chaotic, ad- } \\
\text { hoc and not } \\
\text { documented }\end{array}$ & $\begin{array}{l}\text { Basic processes } \\
\text { are established } \\
\text { and there is } \\
\text { some level of } \\
\text { adherence to } \\
\text { them, some may } \\
\text { be documented }\end{array}$ & $\begin{array}{l}\text { Processes are } \\
\text { well defined } \\
\text { and } \\
\text { documented, } \\
\text { they are } \\
\text { standardized } \\
\text { and integrated } \\
\text { with each other }\end{array}$ & $\begin{array}{l}\text { Process quality } \\
\text { is managed, } \\
\text { data is } \\
\text { collected on } \\
\text { process quality } \\
\text { and reported on } \\
\text { a regular basis }\end{array}$ & $\begin{array}{l}\text { Continuous } \\
\text { improvement } \\
\text { cycles occur with } \\
\text { the process on a } \\
\text { regular basis driven } \\
\text { by business and } \\
\text { technology changes }\end{array}$ \\
\hline
\end{tabular}

At each stage of the maturity level above can be described as follows:

1. Initial is an information technology organization that does not have a procedural model for the process. The success or failure of a process depends on intuitive management competencies or individual skills, knowledge and motivation.

2. Repeatable is the experience of previous projects collected and evaluated. This is the basis of the procedural model for new projects and is stated to be mutually bound. Project objectives, time and costs set, agreed and planned are based on realistic empirical values.

3. Defind is a standard process that is truly documented and applied throughout the company. Which is part of the training and project culture. There is a working group, responsible for the process. Transparent and revised projects / processes.

4. Managed is an organization setting quantitative quality plans for products and processes / projects. Productivity and quality are measured as part of an organization's measurement program. The data is collected, analyzed and used for process evaluation. risk management for new processes is defined and defined.

5. Optimized is an entire organization focused on continuous process improvement. organizations have tools and tools to identify weaknesses and strengthen proactive processes aimed at preventing the occurrence of defects. Innovation is justified through analysis of the cost of benefits from the data collected. Lessons are collected and made available to the public. consistent error analysis aims at preventing errors. The focus is on reducing irregularities and continuous improvement. 


\section{FTTX (Fiber to the $X$ )}

The local Fiber to The $\mathrm{X}$ local cable network has at least 2 passive devices installed in Central Office and the other one is installed near and or at the customer's location (Telkom, 2012). Based on the location of the placement of passive devices installed near and or at the customer's location, there are several configurations, namely: [1],[8],[9],[10]

1. Fiber To The Building (FTTB), Passive devices are located inside the building and are usually located in telecommunications rooms in the basement or spread over several floors, the customer terminal is connected to the Optical Cable Terminal (TKO) through indoor copper cables, FTTB can be analogous to the Direct Supply Area on copper cable networks (Telkom, 2012).

2. Fiber To The Zone (FTTZ), Passive devices are located somewhere outside the building, usually in the form of a cabinet placed on the roadside as usually RK, the customer terminal is connected to an Optical Cable Terminal (TKO) through copper cables up to several kilometers, FTTZ is analogous to RK (Cable Houses) (Telkom , 2012).

3. Fiber To The Curb (FTTC), Passive devices are located somewhere outside the building, both inside the cabinet, on the pole and in Manhole, the customer terminal is connected to the Optical Cable Terminal (TKO) through copper cables up to a few hundred meters, FTTC can be analogous to a Split Point (Telkom, 2012).

4. Fiber To The Home (FTTH), Passive devices are located inside the customer's home, the customer terminal is connected to the Optical Cable Terminal (TKO) through an indoor copper cable or IKR up to several tens of meters, FTTH can be analogous to a Terminal Block (TB) and an OSP (Outsite Plan) project carried out outside buildings / buildings (Telkom, 2012).

\section{Smallworld}

Network inventory management is the foundation of a service provider's operation. Every revenue generating opportunity centers on having accurate up-to-date network information. Smallworld Network Inventory offers telecoms operators an inventory system to control the deployment of the critical network infrastructure on which all end-customer services depend. [17]

The Smallworld Network Inventory product provides a consolidated cross-technology end-to-end view of your next generation network. This comprehensive and integrated view of the entire network combines the fully connected inside and outside plant of the physical network with the services of the logical network. The Smallworld Network Inventory system is an integral part of the Operations Support Systems (OSS) environment supporting critical business processes. A single consolidated network inventory forms the heart of an OSS solution. Through integration with other key systems, Smallworld Network Inventory fulfills a vital role in the planning and engineering, service fulfillment and service assurance processes. [17]

Smallworld Network Inventory is a strategically powerful business resource, providing access to comprehensive, up-to-date network information. Designers, planners, field engineers, marketing, network operations and customer care staff can access inventory data in whatever form is most appropriate, from geographic maps to spreadsheets or database reports via desktop, laptop, field systems, intranet and Internet. [17] Smallworld is the brand name of a portfolio of GIS software provided by GE Energy Connections, a division of General Electric. The software was originally created by the Smallworld company founded in Cambridge, England, in 1989 by Dick Newell and others. Smallworld grew to become the global market leader for GIS in utilities and communications and remains in this position today. Smallworld was acquired by GE Energy in September 2000 [6]

\section{E. As Build Drawing}

ABD (As-Built Drawing) is a development project in the form of an image of the realization of a work that has been carried out, both laying and installation that is useful to determine the condition of each structure in the field so that the existing structure can be a profitable opportunity for the company.[7]

\section{METODOLOGY}

The following is the mindset carried out in this study, because the GE-Smallword inventory system is already running, so it is necessary to evaluate it to determine the extent to which the system services are functioning properly. The framework of thought for this thesis research is as follows : 


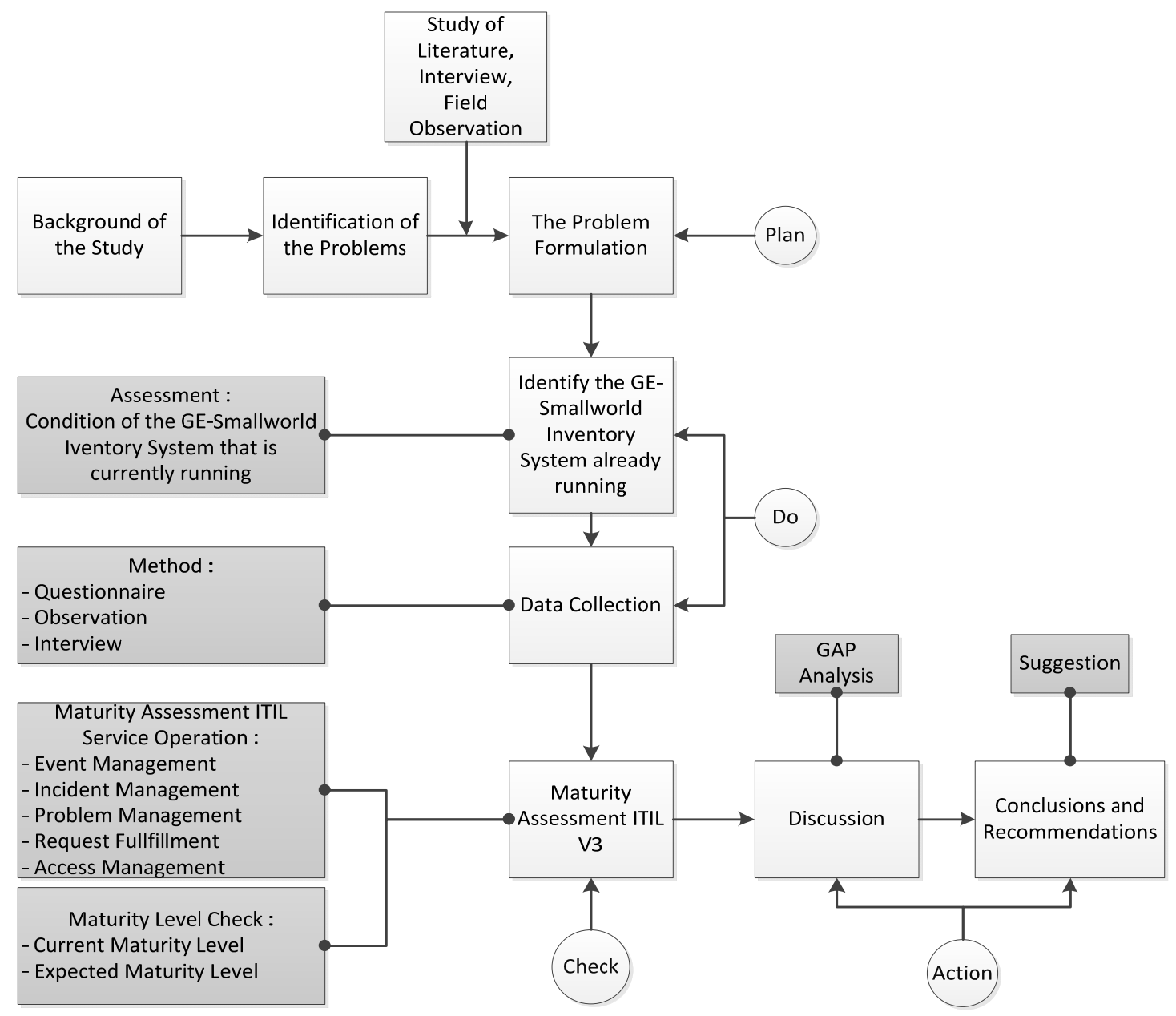

Fig. 4. The Research Framework

The evaluation and analysis method in this study is to compare the results of a system that runs with a system sourced from the literature. The results will be made in graphical form so that it will form the maturity of the ITIL model. The value obtained from the results of data collection and the average rating will be calculated as a result of the evaluation. the level of value used is referring to the theory written by Randy A.Steinberg, 2014 which is between zero and five.

In this study, the tools used are the ITIL method of maturity assessment especially in domain service operations. This assessment process is based on several questions, each of which has a weighting value on each question. This assessment is divided according to the method of ITIL service operation, namely: incident management, event management, request fulfillment, problem management, access management. The questions from each ITIL subdomain service operation are taken from the input and output process flow.

Below is a questionnaire from assessment with ITIL, service operation :

TABLE 2. Event Management Questionnaire

\begin{tabular}{|l|l|l|l|l|}
\hline \multicolumn{5}{|c|}{ Qervice Operation Event Management } \\
\hline No & \multicolumn{1}{|c|}{ Question } & Yes/No & $\begin{array}{c}\text { Current } \\
\text { Value }\end{array}$ & $\begin{array}{c}\text { Expected } \\
\text { Value }\end{array}$ \\
\hline P.1 & Have you done Event Correlation activities? & & & \\
\hline P.2 & Already doing a Response Selection activity? & & & \\
\hline P.3 & Already doing Review Actions activities? & & & \\
\hline P.4 & Already done Close Actions activities? & & & \\
\hline P.5 & Have you done Event Detection activities? & & & \\
\hline P.6 & Already do Event Filtering activities? & & & \\
\hline
\end{tabular}


The above is a quisioner of evaluation with ITIL domain service operation Event Management, P.1 to P.6 are questions 1 to question 6.

TABLE 3. Incident Management Questionnaire

\begin{tabular}{|c|l|l|l|l|}
\hline \multicolumn{5}{|c|}{ Service Operation Incident Management } \\
\hline No & \multicolumn{1}{|c|}{ Question } & Yes/No & $\begin{array}{c}\text { Current } \\
\text { Value }\end{array}$ & $\begin{array}{c}\text { Expected } \\
\text { Value }\end{array}$ \\
\hline P.1 & Already do Incident Identification Activities? & & & \\
\hline P.2 & Already doing Incident Logging activities? & & & \\
\hline P.3 & Already do Incident Categorization activities? & & & \\
\hline P.4 & Already doing Initial Diagnosis activity? & & & \\
\hline P.5 & Already doing Incidentc Escalation activities? & & & \\
\hline P.6 & $\begin{array}{l}\text { Have you done Investigation \& Diagnosis } \\
\text { activities? }\end{array}$ & & & \\
\hline
\end{tabular}

The above is a quisioner of evaluation with ITIL domain service operation Incident Management, P.1 to P.6 are questions 1 to question 6.

TABLE 4. Request Fulfillment Questionnaire

\begin{tabular}{|c|c|c|c|c|}
\hline \multicolumn{5}{|c|}{ Service Operation Request Fulfillment } \\
\hline No & Question & Yes/No & $\begin{array}{l}\text { Current } \\
\text { Value }\end{array}$ & $\begin{array}{l}\text { Expected } \\
\text { Value }\end{array}$ \\
\hline P.1 & Already done the Selection Menu Activity? & & & \\
\hline P.2 & Already doing Financial Approval activities? & & & \\
\hline P.3 & Already doing Fulfillment activities? & & & \\
\hline P.4 & $\begin{array}{l}\text { Have you defined the intent and purpose of Request } \\
\text { Fulfillment? }\end{array}$ & & & \\
\hline P.5 & Have you defined the scope of Request Fulfillment? & & & \\
\hline
\end{tabular}

The above is a quisioner of evaluation with ITIL domain service operation Request Fulfillment, P.1 to P.5 are questions 1 to question 5 .

TABLE 5. Problem Management Questionnaire

\begin{tabular}{|c|c|c|c|c|}
\hline \multicolumn{5}{|c|}{ Service Operation Problem Management } \\
\hline No & Question & Yes/No & $\begin{array}{l}\text { Current } \\
\text { Value }\end{array}$ & $\begin{array}{l}\text { Expected } \\
\text { Value }\end{array}$ \\
\hline P.1 & Already having Problem Review Activities? & & & \\
\hline P.2 & Already done an error detected activity? & & & \\
\hline P.3 & $\begin{array}{l}\text { Have you defined the Input Problem Management } \\
\text { activity? }\end{array}$ & & & \\
\hline P.4 & $\begin{array}{l}\text { Have you defined the Output Problem Management } \\
\text { activity? }\end{array}$ & & & \\
\hline
\end{tabular}

The above is a quisioner of evaluation with ITIL domain service operation Problem Management, P.1 to P.4 are questions 1 to question 4 .

TABLE 6. Access Management Questionnaire

\begin{tabular}{|c|l|l|l|l|}
\hline \multicolumn{5}{|c|}{ Service Operation Access Management } \\
\hline No & \multicolumn{1}{|c|}{ Question } & Yes/No & $\begin{array}{l}\text { Current } \\
\text { Value }\end{array}$ & $\begin{array}{c}\text { Expected } \\
\text { Value }\end{array}$ \\
\hline P.1 & $\begin{array}{l}\text { Already defining Input Activities from Access } \\
\text { Management? }\end{array}$ & $\begin{array}{l}\text { Have you defined the Output Activity from Access } \\
\text { Management? }\end{array}$ & & \\
\hline P.2 & $\begin{array}{l}\text { Have you defined the Interface activity of Access } \\
\text { Management? }\end{array}$ & & & \\
\hline
\end{tabular}


The above is a quisioner of evaluation with ITIL domain service operation Access Management, P.1 to P.3 are questions 1 to question 3 .

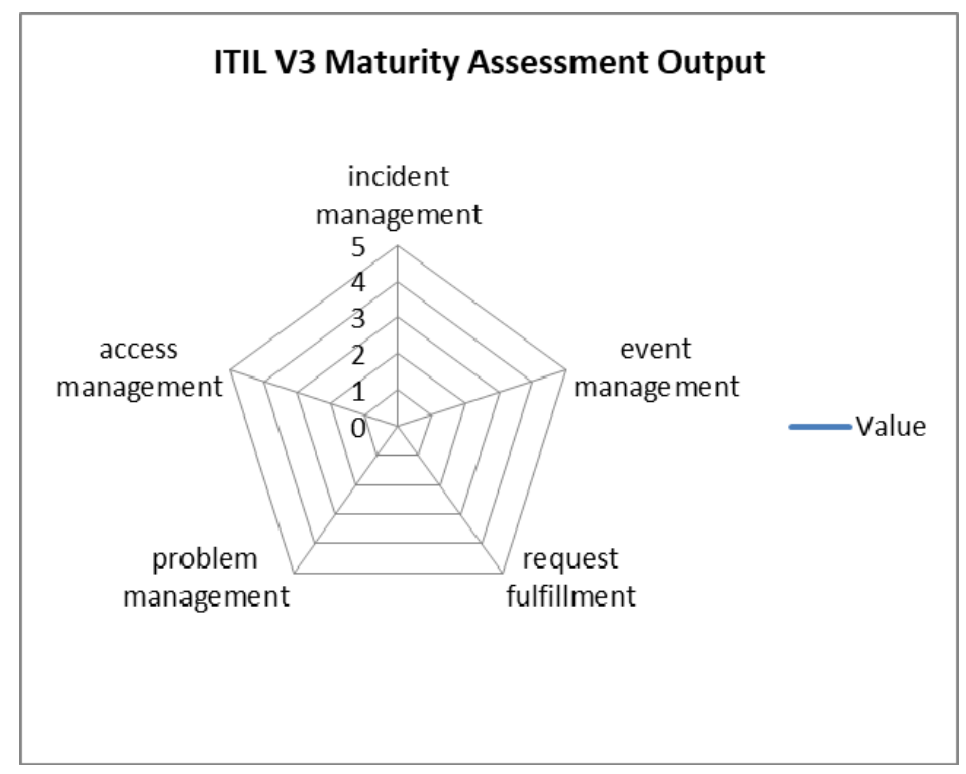

Fig. 5. Maturity ITIL Assessment output

In figure above is a form of research results from the five subdomains that exist in ITIL V3 service operation. There are numbers one to five, the lift is the level of maturity of the system applied. The assessment will be carried out by calculating the average number of questions in the questionnaire and the total of the average value of respondents that will be used for the value of the maturity level.

\section{RESULT}

This study analyzes the extent to which the management of FTTx's optical fiber telecommunications network inventory system that is in GE-Smallworld inventory tools at PT Telkom Access by using the ITIL (Information Technology Infrastructure Library) measuring tool V.3 domain service operation, by ensuring an inventory system runs in accordance with ITIL V3 standards. Domain service operation selection because it serves to provide guidance for conducting service management Information technology including inventory covers all operational activities in managing information system services efficiently and effectively, maintaining operational information system service stability and managing changes in design, scale, space scope and target of information system service performance.

Maturity Assessment aims to determine the level of maturity of the current system, so that it can be used as an initial benchmark and as a reference for the expected maturity level. ITIL v3 variables related to the framework used are event management, incident management, request fulfillment, problem management, and access management.

This assessment serves to determine the quality of the GE-Smallworld inventory system. The calculation uses the average calculation method of taking questionnaire data about the current GE-Smallworld inventory system with the GE-Smallworld inventory system that is expected to be given to respondents simultaneously.

The formula for calculating the average value of the questionnaire is with $\mathrm{X}$ BarAssessment :

$$
\bar{X}=\frac{x_{1}+x_{2}+\ldots+x_{n}}{n}
$$

$n$

After this all the values will be summed and averaged in accordance with the number of respondents, so that the results of the last value with the formula X Double BarAssessment as follows :

$$
\overline{\bar{X}}=\frac{\sum \bar{X}_{i}}{k}=\frac{\bar{X}_{1}+\bar{X}_{2}+\ldots+\bar{X}_{k}}{k}
$$


The table below shows all the results of the assessment and calculation of the average value of the current level of maturity using the ITIL V3 process with the domain service operation. :

1. Event Management

TABLE 7. Current X Bar Assessment Event Management

\begin{tabular}{|l|c|c|c|c|c|c|c|c|c|c|}
\hline \multirow{2}{*}{ Event Management } & \multicolumn{9}{|c|}{ Respondent } \\
\hline \multirow{2}{*}{ Question } & R1 & R2 & R3 & R4 & R5 & R6 & R7 & R8 & R9 & R10 \\
\cline { 2 - 14 } & \multicolumn{9}{|c|}{ Value } \\
\hline Q1.1 & 3 & 2 & 1 & 2 & 1 & 1 & 1 & 3 & 3 & 2 \\
\hline Q1.2 & 3 & 1 & 1 & 2 & 2 & 1 & 1 & 3 & 3 & 2 \\
\hline Q1.3 & 2 & 1 & 1 & 2 & 1 & 2 & 1 & 2 & 3 & 1 \\
\hline Q1.4 & 1 & 2 & 1 & 2 & 1 & 2 & 2 & 3 & 3 & 1 \\
\hline Q1.5 & 2 & 2 & 2 & 2 & 2 & 2 & 2 & 2 & 2 & 1 \\
\hline Q1.6 & 2 & 2 & 2 & 2 & 2 & 1 & 2 & 3 & 2 & 2 \\
\hline Total Value & 13 & 10 & 8 & 12 & 9 & 9 & 9 & 16 & 16 & 9 \\
\hline Total Question & 6 & 6 & 6 & 6 & 6 & 6 & 6 & 6 & 6 & 6 \\
\hline Average & 2.17 & 1.67 & 1.33 & 2.00 & 1.50 & 1.50 & 1.50 & 2.67 & 2.67 & 1.50 \\
\hline
\end{tabular}

From the table above it can be seen the average calculation of each respondent to the GE-Smallworld inventory system questionnaire with domain service operation. The value of R1-R1 is the respondent or participant and Q1-Q6 is a question from the questionnaire.

TABLE 8. Current X Double Bar Assessment Event Management

\begin{tabular}{|c|c|c|c|c|c|c|c|c|c|c|c|c|c|}
\hline \multirow{2}{*}{$\begin{array}{c}\text { Event } \\
\text { Management }\end{array}$} & \multicolumn{10}{|c|}{ Respondent } & \multirow{2}{*}{$\begin{array}{l}\text { Total } \\
\text { Average }\end{array}$} & \multirow{2}{*}{ Total R } & \multirow{2}{*}{$\begin{array}{c}\text { Total } \\
\text { Average/Total R }\end{array}$} \\
\hline & R1 & $\mathrm{R} 2$ & R3 & $\mathrm{R} 4$ & $\mathrm{R} 5$ & R6 & R7 & $\mathrm{R} 8$ & R9 & $\mathrm{R} 10$ & & & \\
\hline Average & 2.17 & 1.67 & 1.33 & 2.00 & 1.50 & 1.50 & 1.50 & 2.67 & 2.67 & 1.50 & 18.50 & 10 & 1.85 \\
\hline
\end{tabular}

In the table above shows the average calculation of the results of the average total of participants in the GESmallworld inventory system that is currently running.

2. Incident Management

TABLE 9. Current X Bar Assessment Incident Management

\begin{tabular}{|l|c|c|c|c|c|c|c|c|c|c|c|}
\hline \multirow{2}{*}{$\begin{array}{c}\text { Incident } \\
\text { Management }\end{array}$} & \multicolumn{9}{|c|}{ Respondent } \\
\hline \multirow{2}{*}{ Question } & R1 & R2 & R3 & R4 & R5 & R6 & R7 & R8 & R9 & R10 \\
\cline { 2 - 13 } & \multicolumn{9}{|c|}{ Value } \\
\hline Q2.1 & 2 & 2 & 3 & 2 & 3 & 2 & 3 & 2 & 3 & 1 \\
\hline Q2.2 & 2 & 1 & 3 & 2 & 2 & 2 & 3 & 2 & 3 & 1 \\
\hline Q2.3 & 1 & 1 & 2 & 2 & 2 & 2 & 2 & 2 & 3 & 1 \\
\hline Q2.4 & 2 & 3 & 1 & 2 & 2 & 1 & 2 & 2 & 3 & 2 \\
\hline Q2.5 & 1 & 2 & 2 & 2 & 1 & 1 & 2 & 1 & 3 & 2 \\
\hline Q2.6 & 2 & 3 & 2 & 2 & 1 & 1 & 2 & 2 & 3 & 2 \\
\hline Total Value & 10 & 12 & 13 & 12 & 11 & 9 & 14 & 11 & 18 & 9 \\
\hline Total Question & 6 & 6 & 6 & 6 & 6 & 6 & 6 & 6 & 6 & 6 \\
\hline Average & 1.67 & 2.00 & 2.17 & 2.00 & 1.83 & 1.50 & 2.33 & 1.83 & 3.00 & 1.50 \\
\hline
\end{tabular}

The table above is the result of the average calculation produced by 10 respondents for questionnaire incident management. 
TABLE 10. Current X Double Bar Assessment Incident Management

\begin{tabular}{|c|c|c|c|c|c|c|c|c|c|c|c|c|c|}
\hline \multirow{2}{*}{$\begin{array}{c}\text { Incident } \\
\text { Management }\end{array}$} & \multicolumn{10}{|c|}{ Respondent } & Total & Total & $\begin{array}{c}\text { Total } \\
\text { Average/Total } \\
\text { R }\end{array}$ \\
\cline { 2 - 13 } & R2 & R3 & R4 & R5 & R6 & R7 & R8 & R9 & R10 & Average & R & 1.98 \\
\hline Average & 1.67 & 2.00 & 2.17 & 2.00 & 1.83 & 1.50 & 2.33 & 1.83 & 3.00 & 1.50 & 19.83 & 10 & 1.93 \\
\hline
\end{tabular}

The table above shows the calculation of the average results of the overall participants for incident management in the running system.

3. Request Fulfillment

TABLE 11. Current X Bar Assessment Request Fulfillment

\begin{tabular}{|l|c|c|c|c|c|c|c|c|c|c|}
\hline \multirow{2}{*}{ Request Fulfillment } & \multicolumn{9}{|c|}{ Respondent } \\
\cline { 2 - 14 } & R1 & R2 & R3 & R4 & R5 & R6 & R7 & R8 & R9 & R10 \\
\hline Q3.1 & 2 & 1 & 3 & 2 & 3 & 1 & 2 & 2 & 2 & 2 \\
\hline Q3.2 & 2 & 1 & 2 & 2 & 3 & 1 & 3 & 2 & 2 & 2 \\
\hline Q3.3 & 2 & 1 & 3 & 3 & 3 & 2 & 3 & 3 & 2 & 2 \\
\hline Q3.4 & 2 & 1 & 3 & 3 & 2 & 2 & 2 & 3 & 2 & 2 \\
\hline Q3.5 & 2 & 2 & 3 & 2 & 2 & 2 & 2 & 2 & 2 & 2 \\
\hline Total Value & 10 & 6 & 14 & 12 & 13 & 8 & 12 & 12 & 10 & 10 \\
\hline Total Question & 5 & 5 & 5 & 5 & 5 & 5 & 5 & 5 & 5 & 5 \\
\hline Average & 2.00 & 1.20 & 2.80 & 2.40 & 2.60 & 1.60 & 2.40 & 2.40 & 2.00 & 2.00 \\
\hline
\end{tabular}

The table above is the result of the average calculation produced by 10 respondents for the Request Fulfillment questionnaire.

TABLE 12. Current X Double Bar Assessment Request Fulfillment

\begin{tabular}{|c|c|c|c|c|c|c|c|c|c|c|c|c|c|}
\hline \multirow{2}{*}{$\begin{array}{l}\text { Request } \\
\text { Fulfillment }\end{array}$} & \multicolumn{10}{|c|}{ Respondent } & \multirow{2}{*}{$\begin{array}{l}\text { Total } \\
\text { Average }\end{array}$} & \multirow{2}{*}{$\begin{array}{c}\text { Total } \\
\mathrm{R}\end{array}$} & \multirow{2}{*}{$\begin{array}{c}\text { Total } \\
\text { Average/Tota } \\
\text { R }\end{array}$} \\
\hline & $\mathrm{R} 1$ & R2 & R3 & R4 & R5 & R6 & R7 & R8 & R9 & R10 & & & \\
\hline Average & 2.00 & 1.20 & 2.80 & 2.40 & 2.60 & 1.60 & 2.40 & 2.40 & 2.00 & 2.00 & 21.40 & 10 & 2.14 \\
\hline
\end{tabular}

The table above shows the average calculation of the results of the average total of participants for the Request Fulfillment on the system that is running.

4. Problem Management

TABLE 13. Current X Bar Assessment Problem Management

\begin{tabular}{|l|c|c|c|c|c|c|c|c|c|c|c|}
\hline \multicolumn{10}{c|}{$\begin{array}{c}\text { Problem } \\
\text { Management }\end{array}$} & \multicolumn{10}{|c|}{ Vespondent } \\
\hline \multirow{2}{*}{ Question } & R1 & R2 & R3 & R4 & R5 & R6 & R7 & R8 & R9 & R10 \\
\cline { 2 - 13 } & \multicolumn{9}{|c|}{ Value } \\
\hline Q4.1 & 2 & 2 & 3 & 2 & 3 & 2 & 2 & 2 & 2 & 2 \\
\hline Q4.2 & 2 & 2 & 3 & 2 & 3 & 1 & 2 & 3 & 2 & 2 \\
\hline Q4.3 & 2 & 1 & 3 & 1 & 2 & 1 & 2 & 3 & 2 & 3 \\
\hline Q4.4 & 2 & 1 & 3 & 2 & 2 & 1 & 1 & 2 & 2 & 3 \\
\hline Total Value & 8 & 6 & 12 & 7 & 10 & 5 & 7 & 10 & 8 & 10 \\
\hline Total Question & 4 & 4 & 4 & 4 & 4 & 4 & 4 & 4 & 4 & 4 \\
\hline Average & 2.00 & 1.50 & 3.00 & 1.75 & 2.50 & 1.25 & 1.75 & 2.50 & 2.00 & 2.50 \\
\hline
\end{tabular}

The table above is the result of the calculation of the average resulting from 10 respondents for quisioner problem management. 
TABLE 14. Current X Double Bar Assessment Problem Management

\begin{tabular}{|c|c|c|c|c|c|c|c|c|c|c|c|c|c|c|}
\hline \multirow{2}{*}{$\begin{array}{c}\text { Problem } \\
\text { Management }\end{array}$} & \multicolumn{10}{|c|}{ Respondent } & $\begin{array}{c}\text { Total } \\
\text { Average }\end{array}$ & $\begin{array}{c}\text { Total } \\
\text { R }\end{array}$ & $\begin{array}{c}\text { Total } \\
\text { Average/Total } \\
\text { R }\end{array}$ \\
\cline { 2 - 11 } & R2 & R3 & R4 & R5 & R6 & R7 & R8 & R9 & R10 & \\
\hline Average & 2.00 & 1.50 & 3.00 & 1.75 & 2.50 & 1.25 & 1.75 & 2.50 & 2.00 & 2.50 & 20.75 & 10 & 2.08 \\
\hline
\end{tabular}

The table above shows the average calculation of the results of the average total of participants for Problem Management in the running system.

5. Access Management

TABLE 15. Current X Bar Assessment Access Management

\begin{tabular}{|l|c|c|c|c|c|c|c|c|c|c|}
\hline Access Management & \multicolumn{10}{|c|}{ Respondent } \\
\hline \multirow{2}{*}{ Question } & R1 & R2 & R3 & R4 & R5 & R6 & R7 & R8 & R9 & R10 \\
\cline { 2 - 12 } & \multicolumn{9}{|c|}{ Value } \\
\hline Q5.1 & 2 & 2 & 3 & 2 & 3 & 2 & 2 & 2 & 3 & 2 \\
\hline Q5.2 & 2 & 2 & 3 & 1 & 3 & 2 & 2 & 1 & 2 & 1 \\
\hline Q5.3 & 1 & 3 & 3 & 1 & 2 & 2 & 2 & 2 & 2 & 1 \\
\hline Total Value & 5 & 7 & 9 & 4 & 8 & 6 & 6 & 5 & 7 & 4 \\
\hline Total Question & 3 & 3 & 3 & 3 & 3 & 3 & 3 & 3 & 3 & 3 \\
\hline Average & 1.67 & 2.33 & 3.00 & 1.33 & 2.67 & 2.00 & 2.00 & 1.67 & 2.33 & 1.33 \\
\hline
\end{tabular}

The table above is the result of the calculation of the average resulting from 10 respondents for Access Management questionnaires.

TABLE 16. Current X Double Bar Assessment Access Management

\begin{tabular}{|c|c|c|c|c|c|c|c|c|c|c|c|c|c|}
\hline \multirow{2}{*}{$\begin{array}{c}\text { Access } \\
\text { Management }\end{array}$} & \multicolumn{10}{c|}{$\begin{array}{c}\text { Total } \\
\text { Average }\end{array}$} & Total R & $\begin{array}{c}\text { Total } \\
\text { Average/Total R }\end{array}$ \\
\cline { 2 - 13 } & R1 & R2 & R3 & R4 & R5 & R6 & R7 & R8 & R9 & R10 & 10 & 2.03 \\
\hline Average & 1.67 & 2.33 & 3.00 & 1.33 & 2.67 & 2.00 & 2.00 & 1.67 & 2.33 & 1.33 & 20.33 & 10 & 2 \\
\hline
\end{tabular}

The table above shows the average calculation of the results of the overall average of participants for Access Management in the system that is running.

From the results of the assessment, a table of maturity values can be made from the GE-Smallworld inventory system under current conditions.

TABLE 17. Maturity ITIL Result the assessment current conditions

\begin{tabular}{|c|c|}
\hline Service Operation & Value of current conditions \\
\hline Event Management & 1.85 \\
\hline Incident Management & 1.98 \\
\hline Request Fulfillment & 2.14 \\
\hline Problem Management & 2.08 \\
\hline Access Management & 2.03 \\
\hline
\end{tabular}

From the table above, a radar graph can be made from the entire ITIL V3 service operation on the system that is running. 


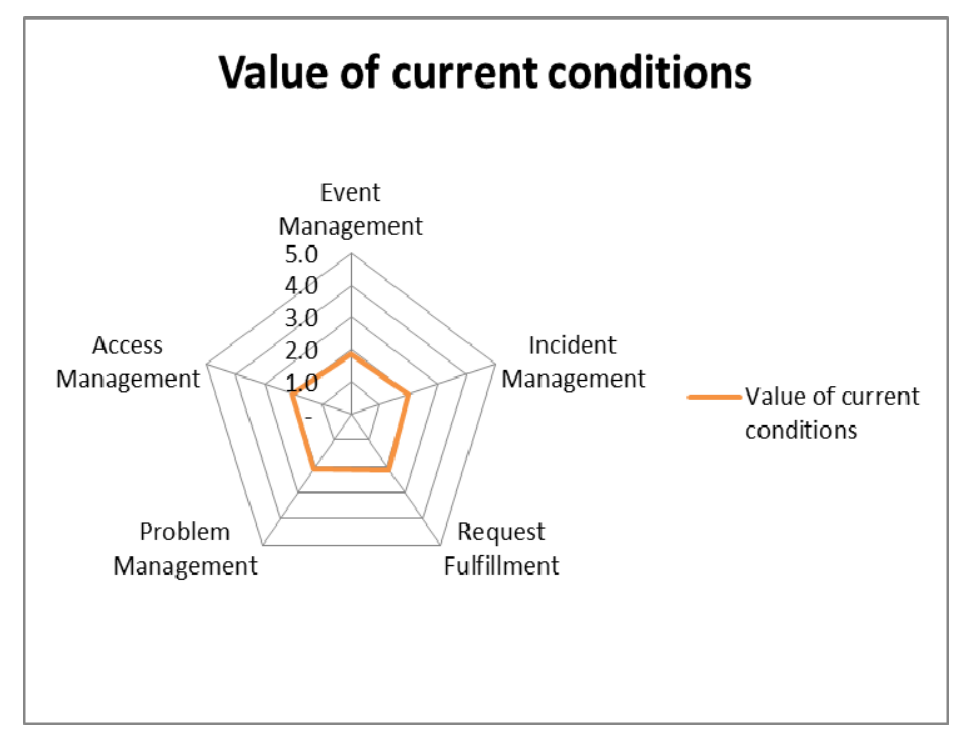

Fig. 6. Maturity current coditions

The table below shows the level of expected maturity value of all the results of the assessment and calculation of the average value of the desired expectations.

1. Event Management

TABLE 18. Expectedt X Bar Assessment Event Management

\begin{tabular}{|l|c|c|c|c|c|c|c|c|c|c|c|}
\hline \multirow{1}{*}{ Event Management } & \multicolumn{10}{|c|}{ Respondent } \\
\hline \multirow{2}{*}{ Question } & R1 & R2 & R3 & R4 & R5 & R6 & R7 & R8 & R9 & R10 \\
\cline { 2 - 15 } & \multicolumn{10}{|c|}{ Value } \\
\hline Q1.1 & 3 & 3 & 2 & 3 & 2 & 3 & 3 & 4 & 3 & 4 \\
\hline Q1.2 & 3 & 2 & 2 & 3 & 2 & 3 & 3 & 4 & 3 & 4 \\
\hline Q1.3 & 3 & 2 & 2 & 3 & 3 & 3 & 3 & 5 & 3 & 4 \\
\hline Q1.4 & 3 & 3 & 2 & 2 & 3 & 3 & 2 & 3 & 4 & 3 \\
\hline Q1.6 & 3 & 3 & 3 & 2 & 3 & 4 & 2 & 4 & 4 & 3 \\
\hline Total Value & 3 & 3 & 3 & 3 & 3 & 4 & 4 & 4 & 3 & 3 \\
\hline Total Question & 18 & 16 & 14 & 16 & 16 & 20 & 17 & 24 & 20 & 21 \\
\hline Average & 6 & 6 & 6 & 6 & 6 & 6 & 6 & 6 & 6 & 6 \\
\hline
\end{tabular}

The table above is the calculation of the average of each respondent on the expected development of event management.

TABLE 19. Expectedt X Double Bar Assessment Event Management

\begin{tabular}{|c|c|c|c|c|c|c|c|c|c|c|c|c|c|}
\hline \multirow{2}{*}{$\begin{array}{c}\text { Event } \\
\text { Management }\end{array}$} & \multicolumn{10}{|c|}{$\begin{array}{c}\text { Total } \\
\text { Average }\end{array}$} & Total R & $\begin{array}{c}\text { Total } \\
\text { Average/Total } \\
\text { R }\end{array}$ \\
\cline { 2 - 12 } & R2 & R3 & R4 & R5 & R6 & R7 & R8 & R9 & R10 & & 3.03 \\
\hline Average & 3.00 & 2.67 & 2.33 & 2.67 & 2.67 & 3.33 & 2.83 & 4.00 & 3.33 & 3.50 & 30.33 & 10 & 3.3 \\
\hline
\end{tabular}

The table above shows the results of the average event management expected in the future. 


\section{Incident Management}

TABLE 20. Expectedt X Bar Assessment Incident Management

\begin{tabular}{|c|c|c|c|c|c|c|c|c|c|c|}
\hline $\begin{array}{c}\text { Incident } \\
\text { Management }\end{array}$ & \multicolumn{10}{|c|}{ Respondent } \\
\hline \multirow{2}{*}{ Question } & $\mathrm{R} 1$ & $\mathrm{R} 2$ & R3 & $\mathrm{R} 4$ & R5 & R6 & R7 & R8 & R9 & $\mathrm{R} 10$ \\
\hline & \multicolumn{10}{|c|}{ Value } \\
\hline Q2.1 & 3 & 3 & 4 & 3 & 3 & 3 & 3 & 3 & 3 & 3 \\
\hline Q2.2 & 3 & 4 & 3 & 3 & 4 & 3 & 4 & 3 & 3 & 3 \\
\hline Q2.3 & 3 & 4 & 3 & 3 & 4 & 3 & 3 & 3 & 3 & 4 \\
\hline Q2.4 & 3 & 3 & 3 & 3 & 4 & 3 & 3 & 3 & 3 & 4 \\
\hline Q2.5 & 3 & 3 & 4 & 3 & 4 & 3 & 3 & 3 & 3 & 4 \\
\hline Q2.6 & 3 & 3 & 4 & 3 & 3 & 3 & 4 & 3 & 3 & 4 \\
\hline Total Value & 18 & 20 & 21 & 18 & 22 & 18 & 20 & 18 & 18 & 22 \\
\hline Total Question & 6 & 6 & 6 & 6 & 6 & 6 & 6 & 6 & 6 & 6 \\
\hline Average & 3.00 & 3.33 & 3.50 & 3.00 & 3.67 & 3.00 & 3.33 & 3.00 & 3.00 & 3.67 \\
\hline
\end{tabular}

The table above is the calculation of the average of each respondent on the expected development of incident management.

TABLE 21. Expectedt X Double Bar Assessment Incident Management

\begin{tabular}{|c|c|c|c|c|c|c|c|c|c|c|c|c|c|}
\hline \multirow{2}{*}{$\begin{array}{c}\text { Incident } \\
\text { Management }\end{array}$} & \multicolumn{10}{|c|}{ Respondent } & \multirow{2}{*}{$\begin{array}{l}\text { Total } \\
\text { Average }\end{array}$} & \multirow{2}{*}{$\begin{array}{l}\text { Total } \\
\mathrm{R}\end{array}$} & \multirow{2}{*}{$\begin{array}{c}\text { Total Average/Total } \\
\text { R }\end{array}$} \\
\hline & $\mathrm{R} 1$ & $\mathrm{R} 2$ & $\mathrm{R} 3$ & $\mathrm{R} 4$ & $\mathrm{R} 5$ & $\mathrm{R} 6$ & $\mathrm{R} 7$ & $\mathrm{R} 8$ & $\mathrm{R} 9$ & $\mathrm{R} 10$ & & & \\
\hline Average & 3.00 & 3.33 & 3.50 & 3.00 & 3.67 & 3.00 & 3.33 & 3.00 & 3.00 & 3.67 & 32.50 & 10 & 3.25 \\
\hline
\end{tabular}

The table above shows the results of the average incident management expected in the future.

3. Request Fulfillment

TABLE 22. Expectedt X Bar Assessment Request Fulfillment

\begin{tabular}{|l|c|c|c|c|c|c|c|c|c|c|c|}
\hline \multirow{2}{*}{ Request Fulfillment } & \multicolumn{10}{|c|}{ Respondent } \\
\hline \multirow{2}{*}{ Question } & R1 & R2 & R3 & R4 & R5 & R6 & R7 & R8 & R9 & R10 \\
\cline { 2 - 13 }$y$ & \multicolumn{9}{|c|}{ Value } \\
\hline Q3.1 & 3 & 2 & 4 & 3 & 3 & 3 & 3 & 3 & 3 & 3 \\
\hline Q3.2 & 3 & 2 & 4 & 3 & 3 & 3 & 4 & 3 & 3 & 4 \\
\hline Q3.3 & 3 & 2 & 4 & 4 & 3 & 3 & 4 & 3 & 3 & 4 \\
\hline Q3.4 & 3 & 2 & 4 & 4 & 3 & 3 & 4 & 4 & 3 & 4 \\
\hline Q3.5 & 3 & 3 & 4 & 4 & 3 & 3 & 3 & 4 & 3 & 4 \\
\hline Total Value & 15 & 11 & 20 & 18 & 15 & 15 & 18 & 17 & 15 & 19 \\
\hline Total Question & 5 & 5 & 5 & 5 & 5 & 5 & 5 & 5 & 5 & 5 \\
\hline Average & 3.00 & 2.20 & 4.00 & 3.60 & 3.00 & 3.00 & 3.60 & 3.40 & 3.00 & 3.80 \\
\hline
\end{tabular}

The table above is the calculation of the average of each respondent on the expected development of request fulfilment.

TABLE 23. Expectedt X Double Bar Assessment Request Fulfillment

\begin{tabular}{|c|c|c|c|c|c|c|c|c|c|c|c|c|c|}
\hline \multirow{2}{*}{$\begin{array}{c}\text { Request } \\
\text { Fulfillment }\end{array}$} & \multicolumn{10}{c|}{$\begin{array}{c}\text { Total } \\
\text { Average }\end{array}$} & $\begin{array}{c}\text { Total } \\
\mathrm{R}\end{array}$ & $\begin{array}{c}\text { Total Average/Total } \\
\mathrm{R}\end{array}$ \\
\cline { 2 - 3 } & $\mathrm{R} 1$ & $\mathrm{R} 2$ & $\mathrm{R} 3$ & $\mathrm{R} 4$ & $\mathrm{R} 5$ & $\mathrm{R} 6$ & $\mathrm{R} 7$ & $\mathrm{R} 8$ & $\mathrm{R} 9$ & $\mathrm{R} 10$ & \\
\hline Average & 3.00 & 2.20 & 4.00 & 3.60 & 3.00 & 3.00 & 3.60 & 3.40 & 3.00 & 3.80 & 32.60 & 10 & 3.26 \\
\hline
\end{tabular}

The table above shows the results of the average request fulfillment expected in the future.

\section{Problem Management}


TABLE 24. Expectedt X Bar Assessment Problem Management

\begin{tabular}{|l|c|c|c|c|c|c|c|c|c|c|c|}
\hline \multirow{1}{*}{ Problem Management } & \multicolumn{10}{|c|}{ Respondent } \\
\hline \multirow{2}{*}{ Question } & R1 & R2 & R3 & R4 & R5 & R6 & R7 & R8 & R9 & R10 \\
\cline { 2 - 14 } & \multicolumn{10}{|c|}{ Value } \\
\hline Q4.1 & 3 & 3 & 3 & 3 & 4 & 3 & 3 & 3 & 3 & 3 \\
\hline Q4.2 & 3 & 3 & 4 & 3 & 4 & 3 & 3 & 4 & 3 & 3 \\
\hline Q4.3 & 3 & 3 & 4 & 3 & 3 & 3 & 3 & 4 & 3 & 4 \\
\hline Q4.4 & 3 & 3 & 4 & 3 & 3 & 3 & 3 & 3 & 3 & 4 \\
\hline Total Value & 12 & 12 & 15 & 12 & 14 & 12 & 12 & 14 & 12 & 14 \\
\hline Total Question & 4 & 4 & 4 & 4 & 4 & 4 & 4 & 4 & 4 & 4 \\
\hline Average & 3.00 & 3.00 & 3.75 & 3.00 & 3.50 & 3.00 & 3.00 & 3.50 & 3.00 & 3.50 \\
\hline
\end{tabular}

The table above is the calculation of the average of each respondent on the expected development of problem management.

TABLE 25. Expectedt X Double Bar Assessment Problem Management

\begin{tabular}{|c|c|c|c|c|c|c|c|c|c|c|c|c|c|}
\hline \multirow{2}{*}{$\begin{array}{c}\text { Problem } \\
\text { Management }\end{array}$} & \multicolumn{10}{|c|}{$\begin{array}{c}\text { Total } \\
\text { Average }\end{array}$} & Total R & $\begin{array}{c}\text { Total Average/Total } \\
\text { R }\end{array}$ \\
\cline { 2 - 10 } & R1 & R2 & R3 & R4 & R5 & R6 & R7 & R8 & R9 & R10 & (10 \\
\hline Average & 3.00 & 3.00 & 3.75 & 3.00 & 3.50 & 3.00 & 3.00 & 3.50 & 3.00 & 3.50 & 32.25 & 10 & 3.23 \\
\hline
\end{tabular}

The table above shows the results of the average problem management expected in the future.

5. Access Management

TABLE 26. Expectedt X Bar Assessment Access Management

\begin{tabular}{|l|c|c|c|c|c|c|c|c|c|c|c|}
\hline \multirow{2}{*}{ Access Management } & \multicolumn{9}{|c|}{ Respondent } \\
\hline \multirow{2}{*}{ Question } & R1 & R2 & R3 & R4 & R5 & R6 & R7 & R8 & R9 & R10 \\
\cline { 2 - 13 } & \multicolumn{9}{|c|}{ Value } \\
\hline Q5.1 & 3 & 3 & 4 & 3 & 4 & 3 & 3 & 3 & 4 & 3 \\
\hline Q5.2 & 3 & 3 & 4 & 3 & 4 & 3 & 3 & 3 & 4 & 3 \\
\hline Q5.3 & 3 & 4 & 4 & 3 & 3 & 3 & 3 & 3 & 4 & 3 \\
\hline Total Value & 9 & 10 & 12 & 9 & 11 & 9 & 9 & 9 & 12 & 9 \\
\hline Total Question & 3 & 3 & 3 & 3 & 3 & 3 & 3 & 3 & 3 & 3 \\
\hline Average & 3.00 & 3.33 & 4.00 & 3.00 & 3.67 & 3.00 & 3.00 & 3.00 & 4.00 & 3.00 \\
\hline
\end{tabular}

The table above is the calculation of the average of each respondent on the expected development of access management.

TABLE 27. Expectedt X Double Bar Assessment Access Management

\begin{tabular}{|c|c|c|c|c|c|c|c|c|c|c|c|c|c|}
\hline \multirow{2}{*}{$\begin{array}{c}\text { Access } \\
\text { Management }\end{array}$} & \multicolumn{10}{|c|}{ Respondent } & \multirow{2}{*}{$\begin{array}{l}\text { Total } \\
\text { Average }\end{array}$} & \multirow{2}{*}{ Total R } & \multirow{2}{*}{$\begin{array}{c}\text { Total Average/Total } \\
\text { R }\end{array}$} \\
\hline & $\mathrm{R} 1$ & $\mathrm{R} 2$ & R3 & $\mathrm{R} 4$ & R5 & R6 & R7 & $\mathrm{R} 8$ & R9 & $\mathrm{R} 10$ & & & \\
\hline Average & 3.00 & 3.33 & 4.00 & 3.00 & 3.67 & 3.00 & 3.00 & 3.00 & 4.00 & 3.00 & 33.00 & 10 & 3.30 \\
\hline
\end{tabular}

The table above shows the results of the average access management expected in the future.

Based on the results of the assessment, a table of maturity values can be made from the system in the expected conditions. 


\begin{tabular}{|c|c|}
\hline Service Operation & Value expected condition \\
\hline Event Management & 3.03 \\
\hline Incident Management & 3.25 \\
\hline Request Fulfillment & 3.26 \\
\hline Problem Management & 3.23 \\
\hline Access Management & 3.30 \\
\hline
\end{tabular}

From the table above it can be made a radar graph of the overall service operation of ITIL V3 on the expected system.

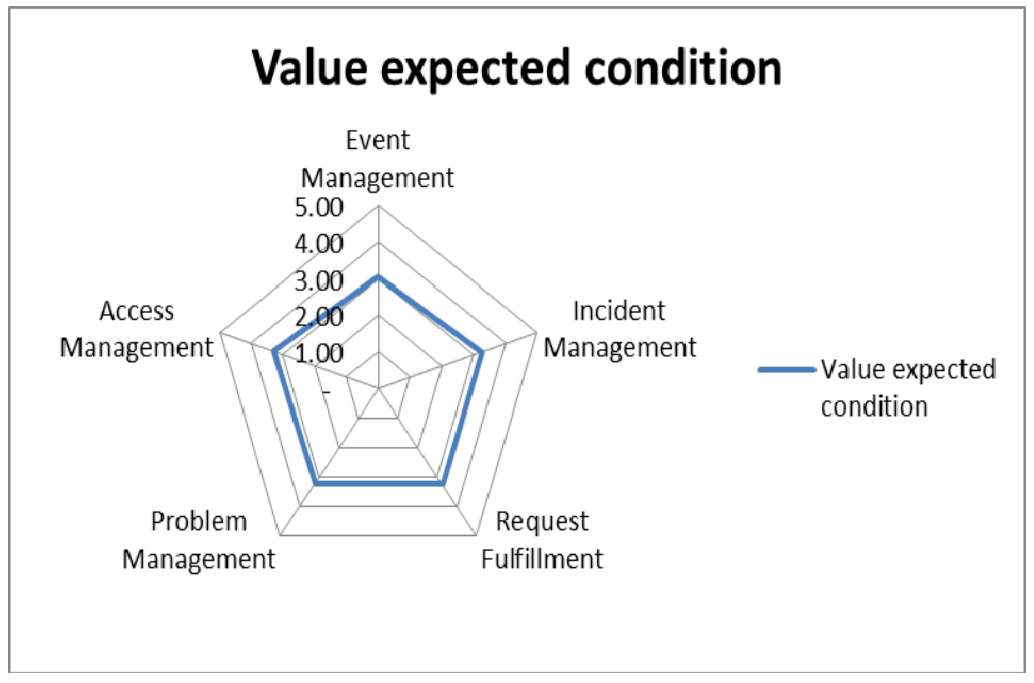

Fig. 7. Maturity Assessment expected coditions

To see a comparison of the results of the system running with the expected system, it will be combined into one table so that there will be a gap. From the results it can be seen that the expected value of the difference is some point from the current system value. Can be seen in the table below:

TABLE 29. Assessment of Operation Service output

\begin{tabular}{|c|c|c|c|}
\hline $\begin{array}{c}\text { Service } \\
\text { Operation }\end{array}$ & $\begin{array}{c}\text { Value of current } \\
\text { conditions }\end{array}$ & $\begin{array}{c}\text { Value expected } \\
\text { condition }\end{array}$ & GAP \\
\hline Event Management & 1.85 & 3.03 & 1.18 \\
\hline $\begin{array}{c}\text { Incident } \\
\text { Management }\end{array}$ & 1.98 & 3.25 & 1.27 \\
\hline Request Fulfillment & 2.14 & 3.26 & 1.12 \\
\hline $\begin{array}{c}\text { Problem } \\
\text { Management }\end{array}$ & 2.08 & 3.23 & 1.15 \\
\hline $\begin{array}{c}\text { Access } \\
\text { Management }\end{array}$ & 2.03 & 3.30 & 1.27 \\
\hline
\end{tabular}

From the results of the table evaluation above, a radar graph can be made with the illustration below. Figure shows the value gap between the system running with the expected system and the different lines 


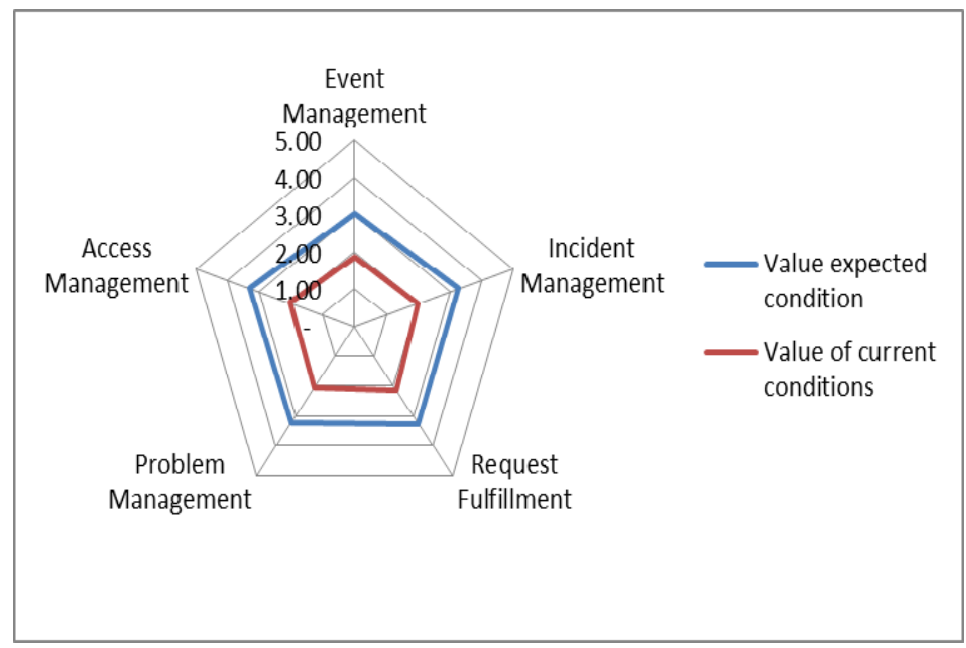

Fig. 8. Assessment of Operation Service output

Here are some gap analyzes which are concluded in the form of a table, there are several obstacles to the occurrence of a gap between the results of a survey of the system that is currently running and the expected system.

TABLE 30. Recommendations from gap analysis

\begin{tabular}{|c|c|c|c|}
\hline Domain & Gap & Impact & Recommendation \\
\hline \multirow{4}{*}{$\begin{array}{c}\text { Service } \\
\text { Operation }\end{array}$} & $\begin{array}{l}\text { Human error is due } \\
\text { to the lack of } \\
\text { accuracy of the } \\
\text { drafter }\end{array}$ & $\begin{array}{l}\text { There are various obstacles } \\
\text { when carrying out } \\
\text { activities at GE- } \\
\text { Smallworld, which are } \\
\text { changestate constraints, } \\
\text { create project constraints, } \\
\text { add splice constraints, } \\
\text { conncetivity constraints, } \\
\text { etc. }\end{array}$ & $\begin{array}{l}\text { There is a control function, and training } \\
\text { for the drafter if there is a renewal of } \\
\text { processes and activities that are not well } \\
\text { understood by the drafter, thus all } \\
\text { drafter get updated info-inifo related to } \\
\text { the mechanism that occurs in the PT } \\
\text { Telkom Access company. }\end{array}$ \\
\hline & $\begin{array}{l}\text { Limited IT } \\
\text { personnel in the IS } \\
\text { (Information } \\
\text { System) section } \\
\text { have a role in } \\
\text { controlling the } \\
\text { operations of GE- } \\
\text { Smallworld } \\
\text { applications }\end{array}$ & $\begin{array}{l}\text { the drafter's performance } \\
\text { has an effect if the } \\
\text { obstacles experienced and } \\
\text { reported snacks are not } \\
\text { fast which results in a } \\
\text { large amount of time } \\
\text { wasted. }\end{array}$ & $\begin{array}{l}\text { The addition of IT personnel in the IS } \\
\text { (Information System) section, so that it } \\
\text { can help control system operations } \\
\text { quickly and if necessary apply the } \\
\text { shifting system so that the system is } \\
\text { monitored at all times by the IT staff on } \\
\text { duty. }\end{array}$ \\
\hline & $\begin{array}{l}\text { System Error } \\
\text { because there are } \\
\text { many users who } \\
\text { access the same } \\
\text { activities in GE- } \\
\text { Smallworld } \\
\text { activities }\end{array}$ & $\begin{array}{l}\text { The drafter cannot log in } \\
\text { GE-Smallworld because } \\
\text { there are many users who } \\
\text { are accessing which results } \\
\text { in heavy applications } \\
\text { while doing GE- } \\
\text { Smallworld activities. }\end{array}$ & $\begin{array}{l}\text { Adding a special server for all activities } \\
\text { that are done at GE-Smallworld, if there } \\
\text { is a need for each STO there are servers } \\
\text { integrated with the central server }\end{array}$ \\
\hline & $\begin{array}{c}\text { Network } \\
\text { constraints. }\end{array}$ & $\begin{array}{l}\text { the drafter cannot do daily } \\
\text { work that has an impact on } \\
\text { the productivity and } \\
\text { performance of the drafter } \\
\text { itself. }\end{array}$ & $\begin{array}{l}\text { Application of incident catalog function } \\
\text { or documentation so that when the } \\
\text { incident returns repeatedly the IT can } \\
\text { handle it quickly. }\end{array}$ \\
\hline
\end{tabular}




\section{CONCLUTIONS}

The valuation tools with ITIL v3 maturity level, the measurement of maturity level in the GE-Smallworld inventory system that has been running and can also be used as an analytical material for benchmarking in achieving an expected increase in inventory systems at PT Telkom Akes. The results of the evaluation and analysis found the level of maturity of the GE-Smallworld inventory system. The conditions at the time of the current are still not optimal, as seen from the expected level of maturity of the system that the drafter wants to achieve. The result is the current system value Event management $=1.85$, Incident management $=1.98$, Request fulfillment $=2.14$, Problem management $=2.08$, Access management $=2.03$ While the value expected by the user is Event management $=3.03$, Incident management $=3.25$, Request fulfillment $=3.26$, Problem management $=3.23$, Access management $=3.30$.

Management of GE-Smallworld inventory tools system basically has run a service operation process which is one of the processes or domains in ITIL V3. SDI Division (Survey Design Inventory) realizes the importance of managing daily operational services, in the GE-Smallwolrd tools system which is an inventory system currently used by PT Telkom Akses. Based on the results of analysis of GE-Smallworld inventory service management it can be concluded that information technology service management is good, judging from the system performance process a day the day was carried out by the drafter, the results of interviews with respondents both the drafter related and with the SPV drafter and supporting documents in the form of standard operating procedures for the GE-Smallworld Invetory system. but at the time of operating the system there were still several problems such as human error, lack of IT personnel in the IS (information system), system error and network errors. So that the performance can be delayed until the problem can be fixed by the parties concerned.

\section{REFERENCES}

[1] Telkom Indonesia(2018,Desember.8)Materi Telkomunikasi PT Telkom Indonesia [online]. Available : http://e-learning.telkom.co.id/

[2] Xiaojun Tang, Yuki Todo, “A Study of Service Desk Setup in Implementing IT Service Management in Enterprises”, June. 2013.

[3] Cartlidge et al, “An Introductory Overview of ITIL $®$ V3”, 2007

[4] Office of Government Commerce. ITIL V3 Service operation. London The Stationery Office,2007

[5] Randy A. Steinberg. "Process maturity scale”, 2014

[6] GE Completes Acquisition of Smallworldwide plc, October 2000

[7] Telkom Akses,(2018,Desember.19). sekilas-perusahaan. Retrieved from telkomakses.co.id [online]. Available : http://telkomakses.co.id/

[8] Telkom Indonesia(2018,Desember.8) Buku pedoman sistem jaringan FTTx PT Telkom Indonesia [online].Available : http://elearning.telkom.co.id/

[9] Bull, Connolly, Eileen, "FTTH Handbook. FTTH Council Europe”, 2012

[10] aryada, Gunardi D.H. "Fiber Optic”. Penerbit Informatika, Bandung, 2015

[11] ITSMF.“An Introductory Overview of ITIL v3” version 1.0, UK Chapter of itSMF. 2011

[12] itSMF “ The IT Service Management Forum”. 2007

[13] Susi Susilowati, "Evaluasi Tata Kelola Layanan Teknologi Informasi Pada Area Service Operation Menggunakan Kerangka Kerja Itil Versi 3”.2012

[14] Sarno, R.” Audit Sistem \& Teknologi Informasi. Surabaya”.2009

[15] TSO.” ITIL Service Operation”. TSO (The Stationery Office).2011

[16] Addy, R.” Effective IT Service Management to ITIL and Beyond!.”.2007

[17] GE Digital Energy.(2018,Desember.16) Smallworld Network Inventory [online]. Available: https://www.gegridsolutions.com/geospatial/catalog/logical_network_inventory.htm 